\title{
Book Review: Foundations of Sustainable Business: Theory, Function, and Strategy
}

\author{
Maria S. Gianni ${ }^{1,2,3 *}$ \\ ${ }^{1}$ Department of Production and Management Engineering, Democritus University of Thrace, Xanthi, Greece, ${ }^{2}$ Department of \\ Mechanical Engineering, University of Western Macedonia, Kozani, Greece, ${ }^{3}$ Department of Business Administration \\ University of Western Macedonia, Grevena, Greece
}

Keywords: management, sustainable development, business school, textbooks, higher education curriculum, sustainability management, corporate sustainability

\section{A Book Review on}

Foundations of Sustainable Business: Theory, Function, and Strategy

Nada R. Sanders, John D. Wood (Wiley Global Education US), 2019, 2nd Edition, 352 pages, ISBN: 978-1-119-57755-3

Sustainability has undisputedly become a mega-trend in the last decades (Lubin and Esty, 2010; Whelan and Douglas, 2021). The sustainability imperative has caused seismic effects on what is

\section{OPEN ACCESS}

Edited by:

Kim Ceulemans,

TBS Business School, France

Reviewed by:

Ingrid Molderez,

KU Leuven, Belgium

Nick Barter,

Griffith University, Australia

*Correspondence:

Maria S. Gianni

giannima@uom.edu.gr;

mgiann@pme.duth.gr

Specialty section:

This article was submitted to

Sustainable Organizations,

a section of the journal

Frontiers in Sustainability

Received: 31 March 2021

Accepted: 10 May 2021

Published: 03 June 2021

Citation:

Gianni MS (2021) Book Review:

Foundations of Sustainable Business:

Theory, Function, and Strategy.

Front. Sustain. 2:688943

doi: 10.3389/frsus.2021.688943 called "business as usual." Sustainable development goals (SDGs) are increasingly used to better envisage the objectives of policies and strategies of governments and organizations (Isaksson, 2021; Vandenbrande, 2021). In this context, companies have adopted sustainable thinking not only in their internal operations but in their interactions with the employees, the customers, the suppliers, the community, and all the other stakeholders. Living and business organizations can be understood as a unified system that absorb resources in order to add value to the product chain and "close the loop" following circular economy models (Prieto-Sandoval et al., 2019; Barreiro-Gen and Lozano, 2020).

University students are the common factor in the equation balancing the objectives of academic institutions and companies. Academics, on the one side, aim to convey knowledge and cultivate skills while companies seek for trained and skilled executives. Furthermore, drawing on stakeholder theory (Freeman, 1984), students are encountered as people-or otherwise stakeholders-that interact and share interests with both the academic institutions and the private or state-owned organizations. This "triangular" relationship calls for a strategic perspective of sustainability curricula. Companies increasingly include sustainable development goals and stakeholder orientation in their strategies. The next generation of quality, the so-called "societal quality," (Deleryd and Fundin, 2020) along with the fourth Sustainable Development Goal (SDG) on quality education have raised educational concerns to a higher level. To serve societal needs, higher education needs to adapt to the new orientation understanding sustainable development as the "golden thread" intertwining university systems (Lozano et al., 2013). The book of Sanders and Wood is a step in the right direction.

The values and principles of sustainable development are presented and discussed in "Foundations of Sustainable Business" through various lenses. The Introduction to Sustainable Business is followed by the Perspectives in the second chapter, where the business case for sustainability is identified based on a holistic view of companies within a social, environmental and economic context. In the next two chapters, sustainable leadership and legal frameworks for sustainability are presented. The role of finance and accounting in sustainability metrics is discussed 
in the fifth chapter. Risk management, marketing, supply chain management, and operations management are addressed in the last four chapters from the sustainability point of view. This stepwise process provides a roadmap for the teacher to gradually "initiate" students into the "mysteries" of sustainability.

As implied by their headlines, all the chapters of the book highlight the common subsets between key parts of a business administration curriculum with sustainability issues. Furthermore, teaching material raises awareness of students who are trained to become future business leaders. The authors are not being judgmental or passively negative to the past and current sustainability shortcomings, but they are rather focusing on what can and should be done by fostering a creative and active standpoint. Compared to other textbooks that either take a more loosely connected stance to management school curriculum (see e.g., Roorda, 2020) or are written for managers (Weybrecht, 2014) or are case-based (Lenssen and Smith, 2019) or industry and IT-focused (see e.g., Pettinger, 2020), Foundations of Sustainable Business stays close to the business school curriculum while providing key sustainability insights.

The complexity of the sustainability topic is tackled with the aid of examples, case studies, definitions, call-out boxes, figures, tables, links to websites, and other digital media resources. In addition, social media references have enriched the second edition of the book. The learning objectives, stated at the beginning of each chapter, are concise and pertinent to the addressed topics. A narrative based on a well-known relevant case introduces readers to the core theme of each chapter. Readers are offered real-life cases and examples aiming to cultivate key sustainability problem-solving competencies, at the same time, in line with the reference framework of Wiek et al. (2011). For instance, in Chapter 2 there is a letter from the former Ph.D. student to her supervisor asking for advice on a water contamination issue.

Using economic terms and tools, such as the externalities and the Kuznets curve, the environmental and social perspectives are integrated with economic growth and complement the core ethics, responsibility, and sustainability themes meeting the needs of a broad business higher education curriculum, as emphasized by Stough et al. (2021). Despite the overall comprehensive content of the book, some topics need clarification to improve comprehension. One of these challenging topics is risk materiality, which is a rather ambiguous concept. Indeed to quantify and calculate risk is a challenging endeavor.

\section{REFERENCES}

Barreiro-Gen, M., and Lozano, R. (2020). How circular is the circular economy? Analyzing the implementation of circular economy in organizations. Bus. Strateg. Environ. 29, 3484-3494. doi: 10.1002/bse. 2590

Deleryd, M., and Fundin, A. (2020). Towards societal satisfaction in a fifth generation of quality - the sustainability model. Total Qual. Manage. Bus. Excellence. doi: 10.1080/14783363.2020.186 4214

Freeman, R. E. (1984). Strategic Management: A Stakeholder Approach. Boston, MA: Pitman.
In this regard, there are two algebraic formulas in the sixth chapter of the book for the risk level and for the magnitude of harm. These formulas may mislead the inexperienced reader to perceive risk quantification as a simple procedure.

Another challenge in the book is the legal particularities of the sustainable business case. The authors lend to the content of the fourth chapter an excellent knowledge on pertinent laws, such as the United States Sarbanes-Oxley Act for the protection of investors and the European Union's regulation for the registration and control of chemical substances $(\mathrm{REACH})$. However, sometimes the reader feels that the legislation on companies' sustainable operations is US-focused. For instance, the EU regulatory framework on company law and corporate governance is missing. Nevertheless, the authors invoke the standards and the guidelines provided by the International Organization for Standardization and the United Nations policies and norms, offering a global perspective to the book.

Overall, the textbook suits well within a modern business curriculum. In more words, the authors manage to tackle the complexity of corporate sustainability following a transdisciplinary approach. The managerial and the global insights, the short stories on leadership and ethical decisions accompanied by recalls of movies, like Erin Brockovich, and real-life cases, such as the Deepwater Horizon oil spill and the Fukushima nuclear power plant accident, attract the interest of the students and emphasize critical meanings. The references at the end of each chapter are up-to-date directing to sources of additional information that allows a more detailed analysis in each aspect of the business case for sustainability. In conclusion, the book is an excellent roadmap for beginners, whether undergraduate or postgraduate students, who look for a wide-scope coverage of the sustainability topic.

\section{AUTHOR CONTRIBUTIONS}

The author confirms being the sole contributor of this work and has approved it for publication.

\section{ACKNOWLEDGMENTS}

The author would like to thank the reviewers for their valuable contribution to the impovement of this book review.

Isaksson, R. (2021). Excellence for sustainability - maintaining the license to operate. Total Qual. Manage. Bus. Excellence 32, 489-500. doi: 10.1080/14783363.2019.1593044

Lenssen, G. G., and Smith, N. C. (2019). Managing Sustainable Business-An Executive Education Case and Textbook. Springer.

Lozano, R., Lozano, F.J., Mulder, K., Huisingh, D., Waas, T. (2013). Advancing Higher Education for Sustainable Development: international insights and critical reflections. J. Clean. Prod. 48, 3-9. doi: 10.1016/j.jclepro.2013.03.034

Lubin, D. A., and Esty, D. C. (2010). The sustainability imperative. Harvard Bus. Rev. 88, 42-50.

Pettinger, R. (2020). The Socio-Economic Foundations of Sustainable Business Managing in the Fourth Industrial Revolution. Switzerland: Palgrave MacMillan. 
Prieto-Sandoval, V., Jaca, C., Santos, J., Baumgartner, R. J., and Ormazabal, M. (2019). Key strategies, resources, and capabilities for implementing circular economy in industrial small and medium enterprises. Corporate Soc. Respons. Environ. Manage. 26, 1473-1484. doi: 10.1002/csr.1761

Roorda, N. (2020). Fundamentals of Sustainable Development, 3rd Edn. London: Routledge.

Stough, T., Ceulemans, K., and Cappuyns, V. (2021). Unlocking the potential of broad, horizontal curricular assessments for ethics, responsibility and sustainability in business and economics higher education. Assess. Eval. Higher Educ. 46, 297-311. doi: 10.1080/02602938.2020.17 72718

Vandenbrande, W. W. (2021). Quality for a sustainable future. Total Qual. Manage. Bus. Excellence 32, 467-475. doi: 10.1080/14783363.2019.15 88724

Weybrecht, G. (2014). The Sustainable MBA: A Business Guide to Sustainability, 2nd Edn. John Wiley and Sons Ltd.
Whelan, T., and Douglas, E. (2021). How to talk to your CFO about sustainability. Harvard Bus. Rev. 99, 86-93.

Wiek, A., Withycombe, L., and Redman, C. L. (2011). Key competencies in sustainability: a reference framework for academic program development. Sustain. Sci. 6, 203-218. doi: 10.1007/s11625-011-0132-6

Conflict of Interest: The author declares that the research was conducted in the absence of any commercial or financial relationships that could be construed as a potential conflict of interest.

Copyright (0) 2021 Gianni. This is an open-access article distributed under the terms of the Creative Commons Attribution License (CC BY). The use, distribution or reproduction in other forums is permitted, provided the original author(s) and the copyright owner(s) are credited and that the original publication in this journal is cited, in accordance with accepted academic practice. No use, distribution or reproduction is permitted which does not comply with these terms. 